\title{
COMMUNITY PERCEPTION ON CLIMATE CHANGE AND USAGE PATTERNS OF NON-TIMBER FOREST PRODUCTS BY COMMUNITIES AROUND KILOLO DISTRICT, TANZANIA \\ *MSALILWA, U., 1 AUGUSTINO, S. ${ }^{2}$ and GILLAH, P.R. ${ }^{2}$ \\ http://dx.doi.org/10.4314/ejesm.v6i5.8
}

Received 10th May 2013; accepted 9th August 2013

\begin{abstract}
Climate change is currently one of the greatest environmental challenges facing humankind; where increased temperatures and changing rainfall patterns are predicted to impact upon livelihoods in Tanzania. This paper highlights the current use pattern of non-timber forest products (NTFPs) by forest-dependent communities as a strategy to cope with the impacts of climate change and variability around the New Dabaga-Ulongambi Forest Reserve (NDUFR) in Kilolo District. Specifically, the local peoples' perceptions of climate change and the change in use pattern of NTFPs as a response to perceived change were investigated. Participatory Research Approaches mainly focus group discussions and household questionnaires were the methods used to collect data. The Statistical Packages for Social Science (SPSS) and content analysis were tools used to analyse data. Further, the Community-based Risk Screening Tool for Adaptation and Livelihoods (CRISTAL 3.0) was used to synthesize information on the link between climate change, NTFPs and livelihoods. The local people perceived changes in climate based on rainfall and temperature in line with the available climatic data records from 1980 to 2011. Temperature has increased for the past 30 years; while rainfall is characterized by large inter-annual variability, with the heaviest rains in 1997 and 2010. Communities living around NDUFR are increasingly relying on NTFPs for food, health and income security among the strategy to cope with change in climate compared to the situation 30 years ago. In conclusion, climate has been varying around forest communities in Kilolo affecting their livelihood. At the same time, NTFPs seem to play safety roles by assisting communities to cope in adverse situations. There is a need for training communities on climate change issues to enhance the adaptive capacity of communities and in turn improve their livelihood. Sustainable harvesting of NTFPs is crucial so as to reduce overexploitation of forest resources.
\end{abstract}

Key words: Climate change; adaptation; NTFPs; Tanzania.

\section{Introduction}

Non-timber forest products are all biological materials other than timber, which are extracted from the forest for the human use (Cocks and Wiersum, 2003). FAO (2001) defined NTFPs as goods of biological origin other than wood, derived from forests, other wooded lands and trees outside the forest. They may be gathered from the wild, or produced in forest plantations, agro-forestry schemes and from trees outside forests (FAO, 1995). Koziell (2001) reported that NTFPs are mainly used for food and medicinal purposes and in both cases can be used for domestic consumption and traded commercially. The most commonly used NTFPs are medicinal plants, wild vegetables, fuelwood, wooden utensils, grass hand-brushes, edible fruits, and twig hand-brushes (Wickens, 1991).

It is widely recognized that climate change has caused substantial impacts on forested

${ }^{I}$ Directorate of Forest Utilization Research, Tanzania

Forestry Research Institute, Morogoro, Tanzania.

${ }^{2}$ Sokoine University of Agriculture, Department of Wood

Utilization, Morogoro, Tanzania.

*Corresponding author: upemsa@gmail.com ecosystems (Parmesan and Yohe, 2003; Kirilenko and Sedjo, 2007). The majority of the forest dependent people have less opportunity to cope effectively with the adversities of climate change due to low capabilities, poverty, weak institutional mechanisms and lack of access to resources (Shackleton and Shackleton, 2004). According to Regmi et al. (2010) climate change adaptation consists of initiatives and measures to reduce the vulnerability of natural and human systems to actual or expected climate change effects.

About 60 million local communities around the globe are estimated to depend on forests (World Bank, 2008). Climate change is currently one of the greatest environmental challenges facing humankind (Totten et al., 2003). Africa was predicted to suffer the most from the impacts of climate change (IPCC, 2001). The changing climatic patterns in Tanzania, such as increased temperatures and changes in rainfall 
patterns, is predicted to have strong impacts on livelihood and biodiversity in the country. Decreasing availability of forest-produce such as food, fuel, medicinal and herbs seem to deprive the rural poor from a supplementary source of income, food and healthcare (Basu, 2009). There is growing evidence that climate change is impacting on forests and forest ecosystems (Mukhopadhyay, 2009); thus need for Tanzania to think of adaptation and mitigation measures and include them through mainstreaming the existing development policies.

Little is known about the local perceptions of climate change and real change by communities living around NDUFR. Furthermore, the role of NTFPs as climate change adaptation strategy and other coping strategies by the communities in the study area is not well known and documented. Information generated from this study provides a timely scientific input to policy-makers during the current implementation of initiatives to combat climate change effects while assisting communities to adapt and sustain their livelihoods. This paper presents an understanding of the local peoples' perceptions on climate change and the roles of NTFPs to forest dependent communities as a strategy to cope with the impacts around NDUFR. Specifically, this study investigated the local perceptions of climate change and the real change by forest dependent communities and examined the current use patterns of NTFPs by household as a strategy to cope with the effect of changing climate and variability around NDUFR.

\section{Methodology}

\section{Description of the study site}

The study was conducted in the selected Participatory Forest Management (PFM) forest dependent communities around NDUFR in Kilolo District, Iringa region (Figure 1). The forest reserve is located between latitudes $35^{\circ} 54^{\prime}$ $\mathrm{E}$ and $35^{\circ} 57^{\prime} \mathrm{E}$ and longitudes $8^{\circ} 01^{\prime} \mathrm{S}$ and $8^{\circ} 06^{\prime}$ S. It covers an area of 3728 ha and is surrounded by six villages namely; Kidabaga, Magome, Isele, Lulanzi, Lusinga and Ilamba. The choice of the study site was based on the very high levels of species diversity and the high reliance of adjacent communities for livelihood security (Lovett, 1998).

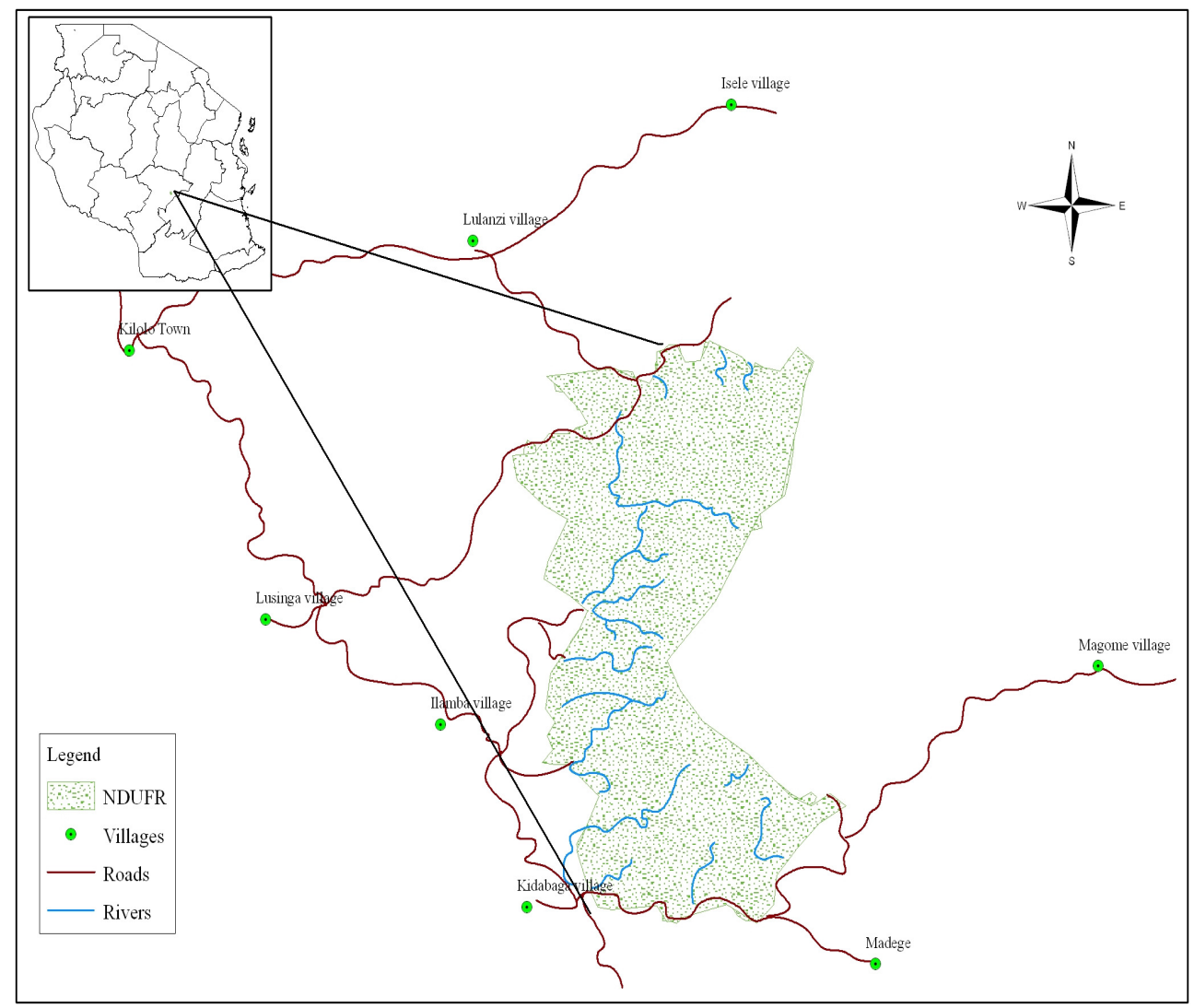

Figure 1Map of NDUFR showing surrounding villages

Source: Frontier Tanzania (2001a). 


\section{Data Collection}

Primary data were collected through household interviews, PRA techniques and direct field observation. PRA techniques and tools as per Regmi et al. (2010) were used to collect general but in-depth knowledge of local people. The tools used were resource mapping to map local climatic hazards; free listing of NTFPs; matrix scoring to get the most important NTFPs; climatic hazard trend analysis to gain insight into the past hazards for the last 30 years; coping and adaptation strategies to assess the effectiveness of the current coping strategies and transect walk to verify the mapping information and identification of NTFPs in the area. Climatic data mainly rainfall, temperature, and other natural calamities for 30 years that occurred in and around NDUFR were obtained from Nduli Airport (IRI/HTIR) weather station.

Data were obtained through interviews using questionnaires. During household interviews, a multi-stage sampling procedure was employed. Four villages surrounding the namely Kidabaga, Magome, Isele and Lulanzi from NDUFR were purposely selected on the basis of closeness to the forest reserve. The selection criterion of the study villages was based on its closeness to the forest. Interviews were administered to randomly selected household members from the list of households in each village. A total of 120 respondents from the four villages were selected for intreveiws.

\section{Data Analysis}

Data collected through PRA tools were analysed with the help of communities and the results communicated back to local communities for rectification. The CRiSTAL 3.0 was used to synthesize information from focus group discussion on the link between climate change, NTFPs and livelihoods. Household interviews data were analysed using Statistical Package for Social Sciences (SPSS) to obtain descriptive statistics such as percentages, frequencies and the results summarised in tables and figures. In this study, chi-square test was used for the significant in dependency on local peoples' perceptions on climate change and socioeconomic factors.

\section{Results and Discussion}

\section{Local perceptions on climate change and variability}

The majority of respondents (81\%) agreed that there have been changes in the climate patterns in the area. The main climatic changes identified by the local people were increase in temperatures and unpredictable rainfalls $(71 \%)$, increase in temperatures $(6 \%)$ and Unpredictable rainfall $(23 \%)$. About $60 \%$ of the respondents agreed that climate change was caused by human activities. The findings are similar to what Maeda et al. (2011) reported where increase in rainfall intensity caused by climate change offer a great risk for soil conservation in the Eastern Arc Mountains. In this study, different perceptions existed as to the causes of climate change where $20 \%$ perceived punishment from God and 12\%, both human activities and punishment from God. Only $8 \%$ of the respondents were uncertain about the causes of climate change and variability (Table 1). This suggests that local people around NDUFR are aware of the causes of climate change and their impacts on their livelihoods.

Table 1 Local perceptions on the causes of climate change and variability

\begin{tabular}{ll}
\hline Cause & $\%$ Response (n) \\
\hline Human activities (cutting trees) & $60(72)$ \\
Punishment from God & $20(24)$ \\
Uncertain & $8(9)$ \\
Human activities and punishment from God & $12(15)$ \\
Total & $100(120)$ \\
\hline
\end{tabular}

Note: Figure in the brackets present frequencies of responses and outside brackets present percentages of respondents.

PRA results showed that local peoples' perceptions on the effects of climate change included increased in temperature, unpredicted rainfall, increased in climatic related diseases and increased in wildfire incidences. The study further revealed that over $50 \%$ of the respondents agreed that climate change started between 10 and 20 years ago while the other half believed that climate change started more than 20 years ago. These results are similar to the 
findings by Akponikpe et al. (2010), where farmers believed that climate change started 15 years ago in Ghana. Matrix scoring results showed that crop productivity was ranked number one being affected by climate change and variability, followed by health of the people living around NDUFR. Also, results by CRISTAL Model revealed that crop production was mostly affected by unpredicted rainfall around NDUFR. High sensitivity of agricultural crops to climate change and variability make the sector vulnerable whenever change occurs.
Maeda et al. (2011) predicted that climate change may affect crop yields by 2030 .

Factors influencing peoples' perceptions on climate change

Table 2 shows the logistic regression model on peoples' perceptions on climate change and variability. Percetion on climate change was different from one individual to another and to some extent influenced by a number of socioeconomic factors such as gender, marital status, age, education, occupation and residence.

Table 2 Logistic regression model on peoples' perceptions on climate change and variability

\begin{tabular}{lllll}
\hline Variable & $\begin{array}{r}-2 \text { Log Likelihood of } \\
\text { Reduced Model }\end{array}$ & $\left(\chi^{2}\right)$ & df & p-value \\
\hline Gender & 39.56 & 0.05 & 1 & $0.82 \mathrm{NS}$ \\
Marital status & 43.04 & 3.53 & 3 & $0.31 \mathrm{NS}$ \\
Age & 45.63 & 6.12 & 2 & $0.04^{*}$ \\
Education & 62.64 & 23.12 & 3 & $0.00^{*}$ \\
Occupation & 42.44 & 2.92 & 2 & $0.23 \mathrm{NS}$ \\
Residence & 45.32 & 5.81 & 2 & $0.05^{*}$ \\
\hline
\end{tabular}

$\mathrm{NS}=$ Non significant, $*=$ Significant at $\mathrm{p}<0.05$.

As shown in Table 2, no significant difference $\left(\chi^{2}=0.05\right.$, df $\left.=1, p=0.82\right)$ was observed between gender and their perceptions on climate change and variability in NDUFR. However, about $48 \%$ and $52 \%$ of female and male respectively agreed that there have been changes in climate. The results suggest that there is significant difference $\left(\chi^{2}=6.12\right.$, df $=2, p=$ 0.04 ) between age of the respondents and their perceptions on climate change and variability in NDUFR. It was learnt that about $60 \%$ of people aged 30 - 60 years agreed that there have been changes in climate in their area. This implies that the elder people have amassed experience and knowledge on changes in climate and variability in the study area.

The results revealed no significant difference $\left(\chi^{2}=2.92, \mathrm{df}=2, \mathrm{p}=0.23\right)$ between occupation of the respondent and perceptions on climate change in NDUFR. About $71 \%$ of farmers, admitted to witness changes in climate in NDUFR. The results also found a significant difference $\left(\chi^{2}=5.81\right.$, df $\left.=2, \mathrm{p}=0.05\right)$ between residence duration of the respondents and their perceptions on climate change and variability in NDUFR. It was learnt that about $51 \%$ had lived in the study area between 30 and 55 years. This would mean that the respondents who have lived in the area for a long period of time have accumulated a lot of experience and knowledge on climate change and variability in the study area.

\section{Changes in temperature around NDUFR}

Majority of the respondents (97\%) agreed that there have been changes in the temperature in the area. There has been an increase in temperature for the more than 20 years ago around NDUFR (Figure 2). Trend analysis of the mean monthly temperature around NDUFR showed a slight increase in the temperature for the last 30 years (Figure 3). Nevertheless, the climatic data records were in line with the peoples' perceptions.

\section{Rainfall changes around NDUFR}

Over $92 \%$ of the respondents agreed that there have been changes in the rainfall patterns over 20 years. They noticed a change not only in the total amount of rainfall but also in the timing of the rains; with rains coming either earlier or later than expected. Figure 6 indicates that $74 \%$ of the respondents noticed an increase in the amount of rainfall or a shorter heavy rainy season (unpredicted rainfall). The trend analysis of the annual rainfall from 1980 to 2011 showed fluctuations with increased annual rainfall (Figure 5). The people's perceptions were in line with the climatic data records. 


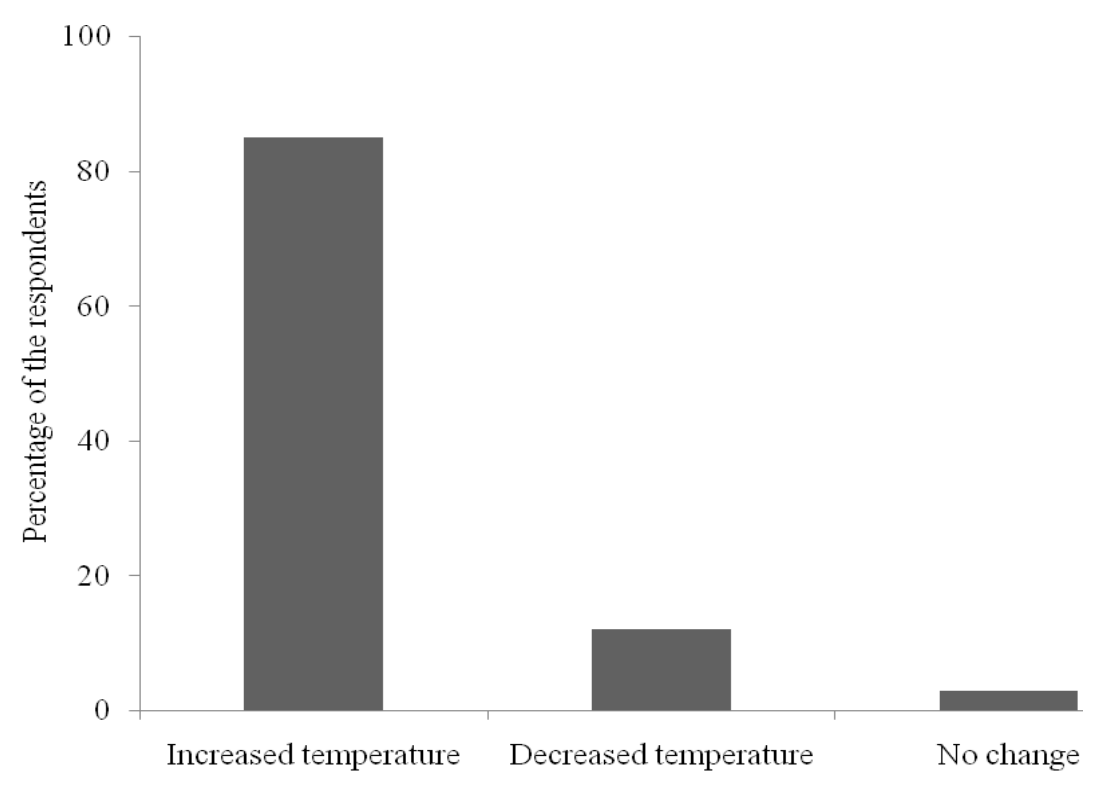

Figure 2 Local perceptions on changes in temperature around NDUFR

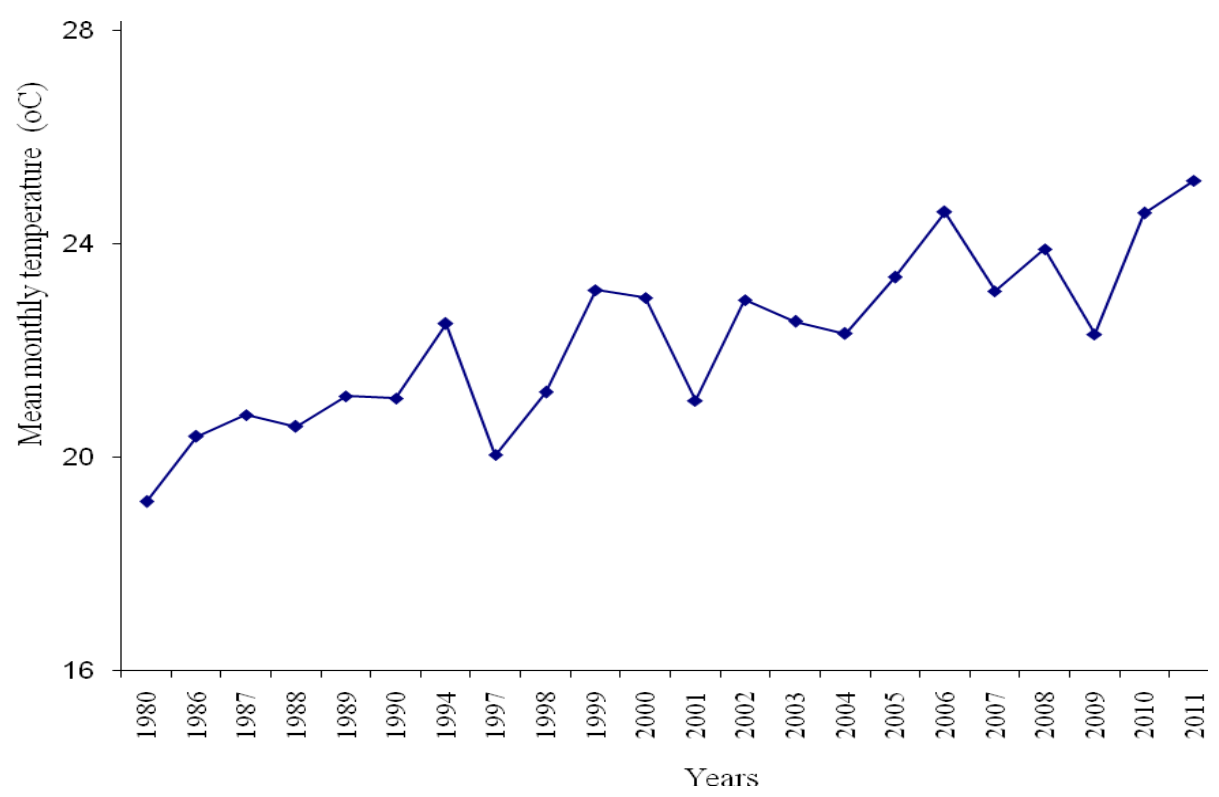

Figure 3 Mean monthly temperature from 1980 to 2011 around NDUFR 


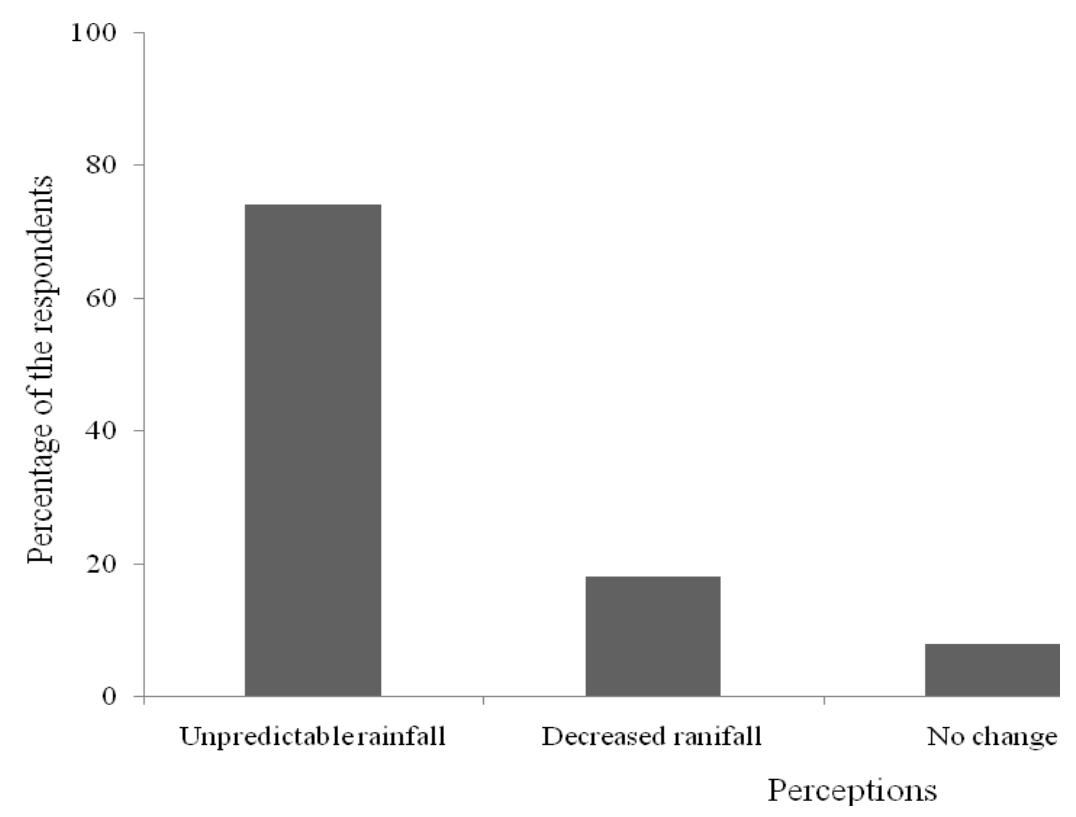

Figure 4 Local perceptions on changes in rainfall patterns around NDUFR

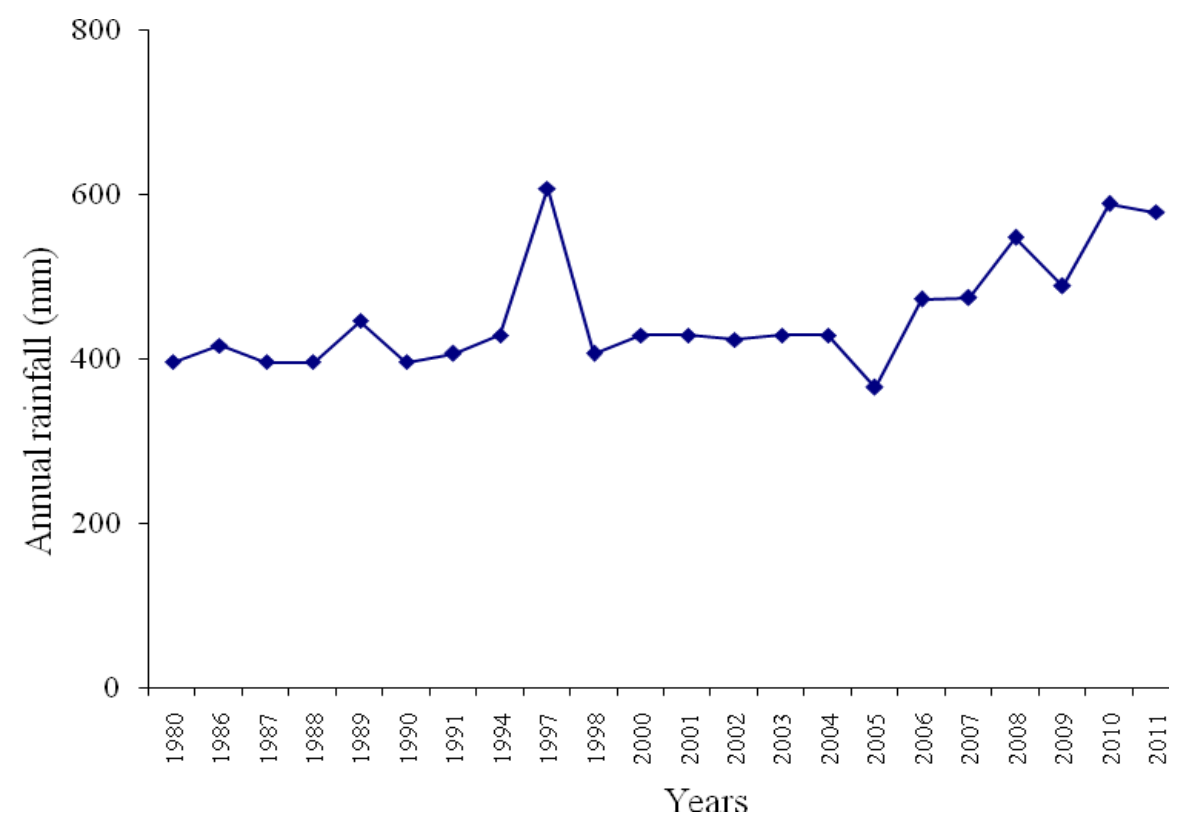

Figure 5 Annual rainfall (mm) patterns from 1980 to 2011 around NDUFR

\section{NTFPs use pattern and Adaptation to climate change and variability}

It was learnt that the demand for NTFPs around NDUFR has gone high with use pattern ranging from food, primary health care and income more than it used to be 30 years ago. Despite this, there is a perceived decrease in availability of NTFPs in NDUFR, a case which need further investigation to confirm. About $43 \%$ of the respondents admitted to consume and sell NTFPs from the forest reserve as the climate change and variability coping strategy. There's high use of NTFPs such as wild vegetables and mushrooms, wild fruits, bush meat, animal feeds, honey, poles, woodfuel, wild animals and medicinal plants as safety nets to cater for food and health care security. NTFPs can either be sold in Kilolo market or Iringa town for the increase of household income. Kitula (2007) reported that a considerable amount of income was made from selling NTFPs. Similarly, a total of 16 edible wild animals were mentioned to be 
harvested from NDUFR. Fresh dung and droppings as well as animal traps were encountered during transect walk confirming the presence wild animals mainly Dik dik, African hare, Bush pig and Stone hyrax. It was learnt that local people hunt game meat mainly for food and sale. Nielsen (2006) found that a total of 14 different animal species were commonly used by the local communities in NDUFR.

It was learned that the demand for NTFPs has increased possibly due to increase in human population around NDUFR and the shortage of NTFPs from the forest. About $86 \%$ of the respondents agreed that there has been a decrease in the amounts of some of NTFPs from the forest reserve. Majority of the respondents believed that the shortage of some NTFPs (i.e. mushrooms, wild vegetables and sedges) was caused by climate change. Local people are forced to use on-farm products instead of NTFPs which have become rare in the forest. The results showed that local people extracted ten (10) different categories of NTFPs from NDUFR. These included medicinal plants, wild vegetables, poles, woodfuel, ropes, shrubs and grasses, honey, bush meat, wild mushrooms and wild fruits. Extraction of resources from the forest was seasonally dependent. Local people extracted NTFPs primarily for meeting household needs, as well as for earning additional income to support or supplement their livelihoods. NDUFR has been providing regulated NTFPs and local communities have benefited from NTFPs (Sumbi, 2004).
The Majority of respondents (82\%) around NDUFR admitted to harvest and use eight (8) different types of wild vegetables. These included Faurea saligna, Sonchus schweinfurthii, Solanum nigrum, Amaranthus spinosus, Caylusea abyssinica, Basella rubra, Oxygonum sinuatum and Cleomea hirta. Wild vegetables are used either fresh or dried for future consumption. Fruits are major source of proteins, vitamins, minerals, fats and roughages. The majority of respondents (72\%) admitted to harvest 11 types of wild fruits from NDUFR. They reported that wild fruits are important food supplement in the village because it provides high nutrition value for family members. Mushrooms were identified as key and rare NTFPs in the study area. Majority of the respondents (83\%) admitted to harvest and consume mushrooms during the wet season. A total of 10 mushroom species harvested from the forest were identified during PRA.

Table 3 shows the amount of NTFPs used and sold per household per year in NDUFR. Honey and beeswax, weaving grasses and medicinal plants were the most traded NTFPs in the area. It was estimated that a household can generate up to 216,992 Tshs per year from selling of NTFPs. Kitula (2007) reported that vendors around NDUFR were capable of realizing a monthly income of up to 200,000 Tsh from selling of plant medicines. The amount of revenue was low because the forest is protected by the village government and the entry to the forest and harvest of NTFPs were through permits.

Table 3 Amount of NTFPs used and sold per household per year in NDUFR

\begin{tabular}{llll}
\hline & $\begin{array}{c}\text { Amount used per } \\
\text { household per year }\end{array}$ & $\begin{array}{c}\text { Average amount } \\
\text { sold per year }\end{array}$ & $\begin{array}{c}\text { Average amount earned per } \\
\text { year (Tshs) }\end{array}$ \\
\hline Wild vegetables (Kg) & 22.7 & 15 & 17,000 \\
Mushrooms (Kg) & 5.8 & - & - \\
Wild animals (Kg) & 15.2 & - & - \\
Wild fruits (Kg) & 29.63 & 150 & 30,000 \\
Honey (Lt) & 7.5 & 30 & 64,992 \\
Ropes (bundles) & 3 & - & - \\
Weaving grasses (piles) & 12 & 25 & 49,000 \\
Medicinal plants (bottles) & 4 & 55 & 55,000 \\
Total & & & 216,992 \\
\hline
\end{tabular}

About $76 \%$ of the respondents reported to utilize honey either as food or as medicine. It was revealed that on average about 7.5 Liters of honey was consumed per household per year. It was consumed as jam or as a side dish in order to increase palatability of the meal. A total of 10 grasses were recorded and identified to be used for different purposes. The main uses included weaving basket and mattress, fodder and roofing. Fodder and thatching grasses are also some of the benefits received by local communities from the forest reserve. Sumbi (2004) reported that local people around NDUFR collect shrubs and grasses for household use and sale. About $67 \%$ of the respondents admitted to obtain shrubs/grasses from the forest reserve. 
It was observed that Cyperus papyrus, Sesamum calycinum and Hyphaene compressa were the three main plant species used for weaving. Cyperus sp., Dactyloctenium aegyptica and Aerva leucura were mainly used for roofing. Dolichos trilobus was mainly used as animal feed. About $34 \%$ of the respondents admitted to use ropes (climbers) for various purposes including hanging beehives, house construction, tying firewood, bed weaving and making baskets. Veltheim and Kijazi (2002) reported similar benefits to local communities in Eastern Usambara Catchment. This study recorded and identified a total of 55 plant species including trees, shrubs and grasses that are used by local people for medicinal purposes.

About $78 \%$ of the respondents admitted that they prefer traditional medicine to manufactured medicines. The main reason cited was the availability and effectiveness of the traditional medicines. The main diseases cured included stomachache, chest ache, fever, colds, allergic reaction and various infections, swelling of breasts, and convulsions. The results further revealed that $86 \%$ of respondents were able to mention more than 15 different plant medicinal species. This indicates that respondents around NDUFR have a wide knowledge on a number of useful medicinal plants, which contribute to the primary health care of their families. Kitula (2007) reported a total of 45 plant species in NDUFR were used as medicines and were readily available throughout the year.

Poles extraction was not common in NDUFR because most of the poles used were obtained from the Black wattle, Eucalyptus and Pine plantations. The results revealed that about 36 tree species could be used as poles from NDUFR. Poles were mainly used for house construction, livestock house construction, business huts and making traditional beds and tool handles. Veltheim and Kijazi (2002) found that local people living around East Usambara Forest Reserve cut different sizes of construction poles for household use and sale. It was revealed that local people prefer to obtain poles from the forest because they are hardwood suitable for making tool handles. The most preferred plant species included Teclea nobilis, Nuxia congesta, Prunus africana, Zanthoxylum gillettii, Albizia gummifera, Bridelia micrantha and Podocarpus latifolius. All in all most of respondents have developed more than one strategy to cope with the current perceived climate change as shown in Table 4.

Table 4 Response on various adaptations as coping strategies to climate change

\begin{tabular}{ll}
\hline Adaptation strategy & $\%$ Response (n) \\
\hline Use of NTFPs & $43(52)$ \\
Diversification of the agricultural crops & $96(115)$ \\
Livestock keeping & $87(104)$ \\
Tree planting & $60(72)$ \\
Conducting petty business & $26(31)$ \\
Timber selling from own farm & $24(29)$ \\
Delay planting & $72(86)$ \\
Use of fertilizers & $42(50)$ \\
\hline
\end{tabular}

Note: Figure in the brackets present frequencies of responses and outside brackets present percentages of respondents

About $96 \%$ of the respondents practice the diversification of crops as a coping strategy to climate change. The main crops intercropped in the growing season included maize, beans, peas and sunflower. Blench (2003) found that farmers minimize or spread risks by managing a mix of crops, crop varieties and sites; staggering the sowing/planting of crops; and adjusting land and crop management to suit the prevailing conditions. In addition, $72 \%$ of the respondents reported to delay sowing seeds due to changes in the rainfall patterns. In West Africa, similar study was done where farmers have been reported to change sowing dates for similar reason (Akponikpe et al., 2010). As an adaptation strategy, local communities (87\%) around NDUFR reported to engage in livestock keeping mainly pigs, chicken, goats and cows. About 57\% of the respondents reported that the existing coping strategies were effective. However, there is a need for the government to develop the local coping strategies by 
communities around NDUFR to allow then adapt effectively with the situation.

\section{Conclusions}

The study concluded that the majority of adjacent local communities around NDUFR have been experiencing changes in the climate patterns. The majority of the respondents agreed that there have been changes in the climate patterns in the area. The main climatic changes include increase in temperatures and unpredictable rainfalls perceived to be caused among other things by human activities. Local peoples' perceptions were in line with the climatic data records. Local communities have already developed their strategies to cope with climate change and variability however, with NTFPs increasing being used at households for food, health as well as selling to generate income, among the strategies. Education level, age and residence duration seem to influence the peoples' perceptions on climate change and variability impacts. Awareness creation on climate change and variability issues, sustainable harvesting, processing and marketing of NTFPs is needed so as to enhance the adaptative capacity of communities and in turn improve their livelihood.

\section{Acknowledgements}

This work would not have been possible without financial support from the Climate Change Impacts, Adaptation and Mitigation Programme in Tanzania (CCIAM) through the project titled: "Climate Change, NTFPs and Livelihood of Forest Dependent Communities: Impacts, Vulnerability and Adaptation in Tanzania" which enabled the fieldwork and other study logistics be accomplished. We are highly indebted to the Kilolo communities, District Forest Officials and other stakeholders for knowledge sharing and data collection facilitation.

\section{References}

Akponikpe, P.B.I., Johnston, P. and Agbossou, E.K. (2010), Farmers' perception of climate change and adaptation strategies in West-Africa. $2^{\text {nd }}$ International Conference. Climate, Sustainability and Development in Semi-arid Regions, August 16-20, 2010, Brazil.

Basu, J.P. (2009). Adaptation, non-timber forest products and rural livelihood: an empirical study in West Bengal, India. Earth and Environmental Science, 6,3-8.
Blench, R. (2003), Forecasts and Farmers: Exploring the Limitations. In: K. O'Brien and C. Vogel (Eds). Coping with Climate Variability. The Use of Seasonal Forecasts in Southern Africa. Ashgate Publishing Limited, Hampshire, England.

Cocks, M.L. and Wiersum, K.F. (2003), The significance of plant diversity to rural households in the Eastern Cape Province of South Africa. Forest Trees and Livelihood, 13, 39-58.

FAO. (1995), Non Wood Forest Products for rural income and sustainable forestry. NWFPs 7, FAO, Rome. Researching factors that influence successful commercialization of Non timber forest products. Lyonia, 5(1), 61-72.

FAO. (2001), State of the World's Forest. Draft Report.

Frontier Tanzania. (2001a), NewDabaga/Ulangambi Forest Reserve - Botanical and Forest Use Report. Doody, K.Z, Howell, K.M, and Fanning, E, (Eds.). Report for the Udzungwa Mountains Forest Management and Biodiversity Conservation Project, Tanzania. $117 \mathrm{pp}$.

IPCC. (2001), Impacts, Adaptation, and Vulnerability. Contribution of Working Group II to the Third Assessment Report of the IPCC, Cambridge University Press, Cambridge. 103pp.

Kirilenko, A.P. and Sedjo, R.A. (2007), Climate change impacts on forestry. Proceedings of the National Academy of Sciences, 104, $19697-$ 19702.

Kitula, R.A. (2007), Use of medicinal plants for human health in Udzungwa Mountains Forests: a case study of New Dabaga Ulongambi Forest Reserve, Tanzania. Journal of Ethnobiology and Ethnomedicine, 3: 7.

Koziell, I. (2001), Diversity not adversity: sustaining livelihoods with biodiversity. International Institute for Environment and Development, London, UK. 74pp.

Lovett, J.C. (1998), Eastern tropical African centre of endemism: a candidate for World Heritage Status? Journal of East African Natural History, 87, 359-366.

Maeda, E.E., Pellikka, P.K.E., Clark, B.J.F. and Siljander, M. (2011), Potential impacts of agricultural expansion and climate change on soil erosion in the Eastern Arc Mountains of Kenya. Geomorphology, 123(3), 279-289.

Mukhopadhyay, D. (2009), Impact of climate change on forest ecosystem and forest fire in India. Earth and Environmental Science, 6(3), 20-27. 
Nielsen, M.R. (2006), Importance, cause and effect of bushmeat hunting in the Udzungwa Mountains, Tanzania: Implications for community based wildlife management. Biological Conservation, 128, 509-516.

Parmesan, C. and Yohe, G. (2003), A globally coherent fingerprint of climate change impacts across natural systems. Nature, 421, 37-42.

Regmi, B.R., Morcrette, A., Paudyal, A., Bastakoti, R., Pradhan, S. (2010), Participatory tools and techniques for assessing climate change impacts and exploring adaptation options: a community based tool kit for practitioners. Nepal. 58pp.

Shackleton, C. and Shackleton, S. (2004), The importance of non-timber forest products in rural livelihood security and as safety nets: a review of evidence from South Africa. South African Journal of Science, 100, 658-664.

Sumbi, P.E. (2004), Community perceptions on costs and benefits of different forest management approaches: A case study of Udzungwa Mountains forests and the surrounding Miombo woodlands, Tanzania. MSc. Dissertation, University of Wales, UK. 116 pp.

Totten, M., Pandya, S.I. and Janson-Smith, T. (2003). Biodiversity, climate, and the Kyoto Protocol: risks and opportunities. Frontiers in Ecology and the Environment, 1, 262-270.

Veltheim, T. and Kijazi, M. (2002), Participatory Forest Management in the East Usambaras. East Usambara Catchment Forest Project. Technical Paper No. 61. Forestry and Beekeeping Division and Metsahallitus Consulting, Dar es Salaam, Tanzania and Helsinki, Finland.

Wickens, G. E. (1991), Management issues for development of non-timber forest products. Unasylva 42(165), 3-8.

World Bank (2008), The World Bank presented a major overhaul to their estimates of global poverty.

[http://beyondthoughts.posterous.com/povertyaround-the-world-global-issues] site visited on 2 June 2013. 